\title{
The Use of Ritual and Ceremony in Strengthening Institutional Affiliation Among First-Year Students
}

\author{
Michael J. Siegel
}

This paper advocates the use of a cultural frame of reference for organizing programs, policies, and procedures in the first year of college. It examines the way in which colleges and universities invoke elements of campus culture, primarily through rituals and ceremonies, to socialize students and strengthen bonds in the campus community in the first year. Discussing two primary ritual types - Rituals of Induction and Rituals of Affiliation - the paper highlights and discusses examples of the practice of using campus culture to acclimate first-year students at select institutions and offers suggestions for identifying and celebrating rituals and ceremonies on campus.

Campus culture can be seen as a blueprint for the way in which structures and other physical properties are arranged and organized at colleges and universities. It can also provide a lens through which one can view campus behavior and deconstruct attendant values and beliefs. Further, it gives an institution identity and provides a perspective through which campus stakeholders make sense of their environment. Applied to the first year of college, the cultural perspective sheds light on the way institutional norms and values are transmitted to entering students.

The primary purpose of this article is to examine the way in which institutions invoke elements of campus culture to socialize students and strengthen studentcampus bonds in the first year. Though it discusses in broad terms the various cultural elements on campus, such as norms of behavior, values, stories, legends, physical artifacts, rituals, sagas, language, myths, symbols, and architecture, it focuses on the use of ritual and ceremony. In this vein, the paper serves as both a perspective for looking at campus culture and a tool for practitioners to use for the purpose of socialization of entering college students. It draws on practices from a handful of colleges and universities that have harnessed the power of ritual and ceremony on campus as a way to facilitate the new student transition process. Finally, the paper offers suggestions for identifying and exploring cultural properties on campus. The discussion aids practitioners in developing a better understanding of the properties of campus culture as they relate particularly to ritual and ceremony.

Michael J. Siegel (msiegel@suffolk.edu) is the Assistant Professor and Director of the Administration of Higher Education Program at Suffolk University in Boston. 
While this paper offers broad definitions of campus culture and suggests a common language to describe cultural properties, its use is not intended to be proscriptive. It describes the various cultural properties extant in the college and university milieu, but focuses more narrowly on the two primary elements that put the culture on display: ritual and ceremony. Importantly, it is incumbent upon practitioners to specifically define culture as it pertains to their own campus and identify those ceremonial and ritualistic aspects of the new student transition experience that serve to acclimate them to the new climate. Fundamentally attempting to understand the institutional ethos and exploring it as a method of socialization of first-year institutional newcomers will be the challenge for practitioners, as campus culture is highly contextual.

\section{The Cultural Perspective}

Adopting a cultural perspective to study colleges and universities is a learning exercise rich with opportunity, particularly where the study of first-year college students is concerned. Not only does it reveal a great deal of information about the often deeply-hidden values and norms of behavior on college campuses, it helps us understand the entering behavior of college students and the role that socialization plays in the process. To be sure, framing ceremonial events on campus in cultural terms - and adopting a cultural perspective to study college campuses - is an undertaking at once vital and illuminating. Colleges and universities continually strive to more deeply connect first-year students to the institution, and using ritual and ceremony is one the primary vehicles for doing so. As Toma, Dubrow, and Hartley (2005) note, "Understanding culture allows an exploration of its uses, particularly the importance of strengthening institutional identification" (p. 55).

The study of culture has long been the domain of the field of anthropology. Early practitioners of the discipline left the groves of academe in the early part of the twentieth century for distant lands to hone their craft of ethnographic fieldwork and lay the foundation for an emerging field of study. Gathering data from its very source and analyzing it through narrative accounts, scholars of the discipline developed a field-based protocol - comprised of observation, interviews and document analysis, and so forth - that has become the standard for qualitative and other forms of academic research. Anthropology has provided social science researchers with a rich and robust methodological means to conduct their work, and it has also left a strong intellectual imprint on the field of higher education. To be sure, anthropology's usefulness as a theory - to explain cultural behavior and symbolism - and as a tool - to conduct fieldwork - makes it a particularly applicable science in terms of discovering and analyzing cultural properties on a college campus. The discipline has not only offered us a way to gather data and analyze elements of culture, it has also given us a language and lens through which we can describe our daily work.

The first step in understanding colleges and universities as culture-bearing organizations is defining the term "culture." Kroeber and Parsons (1958) offer 
perhaps one of the most important and functional definitions, suggesting culture is the "...transmitted and created content and patterns of values, ideas, and other symbolic-meaningful systems as factors in the shaping of human behavior" (p. 582). Noted anthropologist Clifford Geertz (1973), one of the most influential thinkers of the twentieth century, suggests the study of culture is fundamentally an interpretive process. He contends, "...man is an animal suspended in webs of significance he himself has spun, I take culture to be those webs, and the analysis of it to be therefore not an experimental science in search of law, but an interpretive one in search of meaning" (p. 5). It follows that the study of campus culture, for our purposes here, is an interpretive process, subject to the beliefs and values of the people doing the interpreting.

Essentially, Geertz suggests that cultural analyses should be conducted for the purpose of making meaning and interpreting cultural behavior rather than searching for laws that explain it. This is not to suggest that positivism and rationalism do not play a role in cultural analysis, but rather that they alone do not adequately explain cultural phenomenon.

Trice and Beyer (1984), who have broadly studied the role of culture in organizations, suggest that culture primarily contains two components, substances and forms. Substances, according to the authors, are the "networks of meanings contained in its ideologies, norms, and values," and forms are the "practices whereby these meanings are expressed, affirmed, and communicated to members" (p. 654). By first discovering and analyzing the basic forms that are extant in the organizational milieu, researchers are better able understand the deeper meanings that are assigned to organizational practices and behaviors. This is logical, given that visible forms of culture are simply manifestations of deeper, and perhaps less visible, beliefs and values. Perhaps a mining metaphor is useful here. A coal seam in and of itself is not an indication of the quality of the fuel below - only through excavation, both on the surface and in deeper quarters, can the quality be discerned.

Based on Trice's (1984) research, Trice and Beyer (1984) offer a typology (Table 1) that distinguishes between the various commonly articulated cultural forms that are extant in any organization or entity. It provides a general construct of the presence of cultural forms and serves as a useful template for envisioning the role of ritual and ceremony on the college campus.

TABLE 1

\section{List of Definitions that Distinguish Frequently Studied Cultural Forms}

Rite

Relatively elaborate, dramatic, planned sets of activities that consolidate various forms of cultural expressions into one event, which is carried out through social interactions, usually for the benefit of an audience.

Ceremonial Ritual A system of several rites connected with a single occasion or event. A standardized, detailed set of techniques and behaviors that manage 
Myth

Saga

Legend

Story

Folktale

Symbol

Language

Gesture

Physical Setting

Artifacts anxieties, but seldom produce intended, technical consequences of practical importance.

A dramatic narrative of imagined events, usually used to explain origins or transformations of something. Also, an unquestioned belief about the practical benefits of certain techniques and behaviors that is not supported by demonstrated facts.

An historical narrative describing the unique accomplishments of a group and its leaders usually in heroic terms.

A handed-down narrative of some wonderful event that is based in history but has been embellished with fictional details.

A narrative based on true events-often a combination of truth and fiction. A completely fictional narrative.

Any object, act, event, quality, or relation that serves as a vehicle for conveying meaning, usually by representing another thing.

A particular form or manner in which members of a group use vocal sounds and written signs to convey meanings to each other.

Movements of parts of the body used to express meanings.

Those things that surround people physically and provide them with immediate sensory stimuli as they carry out culturally expressive activities. Material objects manufactured by people to facilitate culturally expressive activities.

With their efforts to systematically codify the various cultural forms into a single, meaningful template, the authors have eliminated some of the overlapping and multiple meanings to which any one particular form seems susceptible. Given the abstract and recondite nature of the various cultural forms, it is not surprising that scholars and practitioners alike use some of the terms interchangeably, which can often be problematic.

\section{The Cultural Frame and Implications for Colleges and Universities}

Pinpointing campus culture can be an elusive undertaking. It is place bound and contextual in nature, and it changes as a function of employee migration and immigration in and out of the organization milieu. To that end, culture is stored in people as well as in the physical environment. It is locally-developed and locally-enacted; thus, attempts to apply standard definitions of cultural behavior from one campus to the next ultimately fall short. At best, we can describe the campus environment and label what we see as campus culture. Values, beliefs, norms of behavior, and other properties of campus culture are often so deeply ingrained in the patterns of daily life that organizational members take them for 
granted. It is as if culture is a type of white noise humming along in the background, surfacing only when it is brought to our collective attention through ritual and ceremony. Essentially, such public performances put culture on display.

Borrowing anthropological terms and applying them to our everyday work in academe requires that we take into account the cultural foundations upon which campus events rest and from which they emanate. That is, campus culture is fundamentally institution-specific. The boundaries around which cultural properties are drawn on any given college campus are determined by history and tradition as well as the institutional actors associated with them.

The use of anthropological concepts to explain the college environment has been well-established in the higher education literature. Several researchers (Kuh \& Whitt, 1988; Kuh, Siegel, \& Thomas, 2001; Magolda, 2001; Manning, 2000; Trice \& Beyer, 1984) have examined the college and university environment using a cultural perspective as frame of reference - or theory-in-use - for both describing and analyzing organizational behaviors, structures, policies, and beliefs. For the purposes of this paper, Kuh and Whitt (1988) provide perhaps the most vivid, comprehensive, and useful definition of campus culture. Culture, according to the authors, can best be defined as:

...the collective, mutually shaping patterns of norms, values, practices, beliefs, and assumptions that guide the behavior of individuals and groups in an institute of higher education and provide a frame of reference within which to interpret the meaning of events and actions on and off campus. (pp. 12-13)

To understand cultural aspects of rituals, ceremonies, and symbolic campus events, we must fully understand the history and traditions of the campus as well as the people who have shaped institutions over the years.

\section{Ritual and Ceremony: The First College Year}

Favoring a narrower rather than broader application of Trice and Beyer's cultural forms to the college and university milieu, I would like to focus on two cultural aspects that provide perhaps the best window into the complexities of campus life, particularly in the first year of college: rituals and ceremonies.

Manning (2000) offers perhaps the most comprehensive picture of campus culture related to ritual and ceremony. While the genre of campus culture literature focuses broadly on multiple aspects of college life - presidential inaugurations, Founders' Day, Convocation, Graduation, and the like - very few studies or essays target the first college year as the primary unit of analysis.

To understand the role and function of cultural forms for the purposes of this paper, and to distinguish between the concepts of rites and ceremonies, a caveat is in order. Though the terms "rite" and "ritual" are different in the definitional sense (see, for example, Trice \& Beyer, 1984), they are often used interchangeably, and as such will be used in the same manner here. Rites, according to Trice and Beyer (1984), are "relatively elaborate, dramatic, planned sets of activities that consolidate various forms of cultural expressions into one event, which is carried out through social interactions, usually for the benefit of an audience" 
(p. 655). They typically are major events in individuals' lives that mark a symbolic change from one state of being or lifestyle to another. Van Gennep (1909; 1960) first discussed the concept of rites of passage, which included those events fertility rites, baptism, funerals, purification ceremonies, marriages, and the like - that mark a significant transition in many Western and non-Western cultures. Through performances both public and private, campus rituals function simultaneously as bonding agents (for cultural preservation) and agents of transformation (for cultural change). As Manning (2000) puts it, "Rituals maintain while simultaneously transform campus cultures" (p. 2).

Ceremonials represent a "system of several rites connected with a single occasion or event" (Trice and Beyer, 1984, p. 655). In that vein, ceremonial events inform the larger, overarching rites. Take for example, the rite of passage of graduation on college campuses. The graduation event, so to speak, is the overarching concept or rite. The various individual or smaller events that, taken together, comprise the concept of graduation are ceremonials. So where graduation is the rite of passage, the discrete events that give it meaning - the robing of the participants, the procession to the stage, the conferral of degrees, and the playing of "Pomp and Circumstance," for example - are the ceremonial aspects.

Campus cultural properties - particularly rituals and ceremonies - are like moorings that tether students intellectually and cognitively to their college or university. Whether or not these moorings are as secure and effective as they need to be is a question that each institution must answer for itself; it can be surmised, however, that institutional loyalty among today's college students has diminished somewhat. As evidence, consider the relative ease (and frequency) by which students migrate from one campus to another in search of an academic home, sometimes attending more than one institution at a time in the process. With the college commuter student population representing an increasingly larger percentage of the overall college-going population, traditional transmitters of socialization - the residence life experience, Convocation, Orientation, and first-year learning communities, for example - are seemingly becoming less meaningful to larger numbers of entering students. This alone makes the celebration of ritual and ceremonial traditions in bonding our students to the campus that much more important and vital.

I suggest here two types of ritualistic events, or phases, that punctuate the first college year and the transition process of new students entering into the campus environment. They are: Rituals of Induction and Rituals of Affiliation. I offer six instructive examples that highlight the intentional use of ritual and ceremony as a means of forging bonds with entering students. Practitioners can draw upon models when thinking about the use of rituals and ceremonies on their own campuses.

\section{Rituals of Induction}

The ritual of entering college life begins first with the leave-taking process. 
After countless campus tours, Welcome Weeks, Alumni gatherings with prospective students, and days spent combing through the crush of admissions and branding materials - perhaps we can appropriately call these Rituals of Allure and Inducement, which are altogether different types of rituals - students pack their belongings, take the proverbial vow of poverty, and, sans family and loved ones, start their academic journey. When they pass through the ivy gates, they soon partake in Rituals of Induction.

These rituals concern the process by which students are initiated into the campus community and inculcated with the various norms, values, and behaviors extant on campus. Essentially, students are vested in the process of becoming a student at that particular college or university, and they become part of a larger group of similarly situated students. Related ceremonies take the form of induction ceremonies, Convocations, oaths and adherence to honor statements, and Orientation events, for example. Such rituals of entry begin with the symbolic leaving process that students experience when they separate from their family and friends and begin the transition into the college environment.

A fascinating induction rite ceremonial is the Kenyon College Matriculation Oath (Kenyon College, 2007), a tradition that was first instituted at the Ohio college in 1841 and exists to this day. The Matriculation Oath is administered to all first-year students at the College's Founder's Day Convocation, and it includes two parts. In the first part of the oath students promise to obey the rules and regulations of the College, and in the second part they pledge to promote the welfare of the College. Students are also expected to inscribe their name in what is called the Matriculation Book, an historic tome housed in the College's library which documents the long line of students that have come through Kenyon's doors. The symbolic inscription process represents an authenticated agreement between two parties to mutually endorse and support one another.

Like many campus rituals, the Convocation ceremony at Elon University in North Carolina is inextricably linked to the very ethos of the college's mission. Nestled among the bucolic campus grounds are many oak trees, and the college, situated in a former oak grove, is properly named: "Elon" means oak in Hebrew (Yale Daily News, 2007). At Fall Convocation each year, every new student is given an acorn when recessing from the event, a richly symbolic gesture marking the beginning of their growth as Elon students. As a bookend to the experience, graduating seniors are given a small oak sapling to plant, a fitting symbolic event marking their growth as students from acorns to saplings and their potential growth into future oak trees. As the president spoke eloquently at a recent Fall Convocation, "Today, we plant the seed symbolically, that will germinate and grow into that small tree you'll receive at commencement. Keep your acorn as a reminder that you have within you everything you need to grow and become strong" (Smith, 2005). The two ceremonies are connected by a representational thread that serves as a meaning making device and connects the whole of the academic experience at Elon University. In essence, the simple conferral of the sapling at the graduation ceremony closes the loop and brings closure. Most importantly, it connects students to each other - and to thousands of fellow alumni - as well, and roots 
them to the institution in significant ways.

Texas A \& M University is awash in traditions, and it is justly renowned for its public, deeply-embedded, and typically spectacle-sized rituals that bring the Aggie community together. A unique university ritual in which thousands of Aggie faithful participate annually is "Fish Camp" (Texas A \& M University, 2004). First-year students, affectionately called fish, congregate at an off-campus encampment for four-days of ritualistic orientation activities, where they are led by volunteer student counselors who engage them in team-building activities and tutor them in Aggie traditions, values, songs, and cheers. Students are divided into one of six campuses, each one named for a Texas A \& $M$ individual who has contributed a great deal to the campus community (Texas A \& M University, 2006). Started in 1954 as a camping trip by a former campus activities director, the initial small gathering of campers has turned into a four-day bazaar featuring some 4,800 first-year students and 900 camp counselors.

As each of the cases above illustrates, the common ritual on display is one of induction, inculcation, and investiture. The attendant ceremonies - oath-taking rites at Kenyon, artifact-bestowing customs at Elon, and off-campus bonding traditions at Texas A \& M - comprise the ritual and give it meaning.

\section{Rituals of Affiliation}

Rituals of Affiliation concern the engagement of students in the life of the college - intellectually, cognitively, and emotionally - as a means to further strengthen the institution-student bond. As Young (1999) says, "A ritual is a learning activity that is grounded in the spirit of community. It helps individuals connect their life experiences, questions, and answers to those of other people" (p. 11). It is precisely this premise - that rituals connect people through symbolic activities in an attempt to foster community - that guides the concept of Rituals of Affiliation. I consider these rituals to be an extension, or continuation, of the aforementioned induction rituals. That is, they are enacted for the purposes of weaving those that have been inducted into the community more deeply into the fabric of the institution.

Rites of Affiliation, whether by consequence or design, encourage students to engage in communal behaviors around a symbolic occurrence that celebrates the values of the campus, a very important prospect given the fractured state of student life on many campuses and the role that technology has played in alienating many students from their peers. Homecoming Weekends, Parents' Weekends, Fall football weekends, and number of Fall Festivals are time-honored traditions that play out every year on the nation's college campuses with the intent of cementing the bond between students and their institution.

Salem College, a women's college founded in 1772 in Winston-Salem, North Carolina, is steeped in affiliation traditions that help build kinship among the faculty, staff, and students. Every year the college community comes together for Fall Fest (Salem College, 2002), an all-day event where classes are cancelled and students compete for various spirit awards. The night before Fall Fest is a special 
event for first-year students, as each one is introduced to a junior who become, in effect, her big sister. This mentoring relationship continues until the big sister graduates, at which time the little sister has become a junior; as the cycle begins anew, she becomes a big sister.

Another ritual of note, this one tied to a holiday tradition, occurs each year at The College of William and Mary, a small, public university and one of the country's original Colonial Colleges. The annual celebration, called the Yule Log Ceremony (The College of William and Mary, 2005), ends the fall semester each year and includes a host of ritualistic events, quite captivating indeed for first-year students. Perhaps the most anticipated event is the entrance of the President of the College, dressed in full Santa garb, who greets the gathering and reads a rendition of "How the Grinch Stole Christmas," a tradition that has been in place since the 1970s. As the ceremony continues, the Vice President of the College offers another pleasurable serving to the masses by reciting " $\mathrm{T}$ 'was the Night After Finals," a poem tailored to the college and spoken in the tradition of " $\mathrm{T}$ 'was the Night Before Christmas." The text is often updated to reflect new happenings at William and Mary. At the close of the service, the Yule Log is carried through the crowd of students, who ceremoniously touch the logs with sprigs of holly they have been given. Those gathered pass through what is called Wren's Great Hall, where the Yule Log fire is now burning, and toss their holly into the fire, an act, according to the college's Web site, that signifies, "the casting away of old worries and cares and an embracement of new hope and opportunities for the future" (The College of William and Mary, 2005).

One of the most interestingly kinetic collegiate rituals is the migratory march of Williams College football players through town after a Homecoming win, which is simply know as the "The Walk" (Williams College, 2007). The Walk is a part of the Homecoming tradition, and it takes place if the team, known as the "Ephs," comes out victorious. On any given Homecoming Saturday, the casual observer might witness the senior team captains leading hundreds of Williams faculty, staff, administrators, alumni, and fans from the field of victory to downtown Williamstown, where the revelers will enjoy cold drinks and sing popular Williams songs in front of St. Pierre's Barber Shop. It is not uncommon for the occasional member of the football team to have his head shaved. The spectacle, according to the college's Web site, has been named by Sports Illustrated and ESPN as one of the great fall football traditions (Williams College, 2007).

For those who miss The Walk, there is always the opportunity to engage in other ritualistic marches, such as the climb to Stony Ledge that takes place during the annual Williams College Mountain Day celebration. It is described in the following passage:

One beautiful Friday morning in October, Williams President Morton Owen Schapiro (lovingly known to Williams students as "Morty"), wakes up, looks out of his window, and declares that the day is just too beautiful to spend indoors. Thus, he cancels all classes and calls for Mountain Day in a tradition that dates back to 1830. Mountain Day is one of the most beloved Williams traditions because it helps students and faculty alike to embrace the 
beauty of the Berkshires....The majority of the student body and many faculty and staff climb to the top of nearby Stony Ledge... where we enjoy donuts and hot cider while listening to choral and musical performances. The highlight of the day is always a group singing of our school song, fittingly entitled "The Mountains," which echoes through the valley (Williams College, 2007).

Such rich and long-held (and purposeful) traditions have endeared thousands of Williams students to the institution; to be sure, these rituals of affiliation have enhanced students' sense of belonging and their connection to something larger than themselves.

Again, the common ritual celebrated by the above institutions is related to forms of campus affiliation, community-building, and bonding. The attendant ceremonies - Fall Fest at Salem College, the Yule Log Ceremony of William and Mary, and The Walk at Williams College - all provide a communal atmosphere where various institutional actors convene celebrate campus values, beliefs, and traditions.

\section{Recommendations}

Several of the rituals mentioned above are the domain of small, typically private, liberal arts colleges. Indeed, many academics and lay persons alike immediately conjure images of such institutional types when history, tradition, values, mission, ritual, and ceremony are mentioned. The genre of the academic novel seems primarily draws from the small college environment, perhaps because of the typically longer history of private institutions. Indeed, many colleges stem from religious origins, which may explain some of the tradition, ritual, and ceremony. Surveying the virtual landscape of colleges and universities, it is readily apparent that small colleges tend to be more likely to draw attention to and display their traditions, rituals, and ceremonies. The following are items that practitioners (both at large and small and public and private institutions) should consider when identifying, documenting, and celebrating campus rituals and ceremonies for the purposes of community-building and culture transmission:

- Institutions should organize a group of individuals on campus who have a vested interest in the culture of the academy and who would serve the campus as arbiters of campus traditions. Wake Forest University students recently started a "traditions council" (Giovanelli, 2006) on campus that meets to consider new customs and celebrate old ones.

- Institutions should identify what rituals and ceremonies, if any, exist on campus and document as many details as possible to explain and describe the rituals. Every effort should be made to record in writing the oral traditions surrounding the rituals, the names of founders, the dates they began, the reasons for their implementation, the impressions various groups of people - faculty, students, staff, administrators, alumni, and so forth - have about the events, and any other important baseline information which might help in the promotion of the event. Further, an examination of language, stories, sagas, and oral traditions that surround 
campus rituals and ceremonies is paramount.

- In documenting the cultural performances, rituals, and other ceremonial behaviors that take place on campus, it is important that events-both small and large-have an impact. Some events might be expansive and engage a campus-wide gathering, and others might emanate from one or two organizations and include a relatively small number - in the scope of things, they might be equally as important as powerful symbolic experiences.

- Locate and identify the people, departments, units, and physical properties through which rituals and ceremonies are developed and displayed. Where do rituals take place on campus, and who typically oversees their enactment?

- Understand fully how your campus organizations and departments contribute to college traditions and participate in the ritualistic aspects of the campus environment.

- Avoid using rituals and ceremonies as mechanisms of social control, whether subtle or otherwise, and also be cognizant of the way in which mixed messages might be sent by multiple organizational actors or units on campus. Similarly, institutions will want to be careful not to promote or endorse campus rituals that are, at best, deleterious to the well-being of the institution, and at worst, exclusive and even demeaning.

- Examine the language and messages that are sent by the college community before, during, and after campus rituals, noticing any themes that emerge. Also, examine written materials on campus related to rituals and traditions (the campus Web site, marketing and branding materials, and orientation documents, for instance) for cultural properties.

\section{Conclusion}

The exploration of causal, or even relational, connections between campus rituals and higher levels of engagement, retention, and success goes beyond the scope of this paper. As such, we can only make tacit assumptions about the role of campus rituals and ceremonies in enhancing these important aspects of college life. The prospects, however, for developing new - and nurturing old - rituals in a formalized manner to such ends are promising indeed. We know that thoughtfully-conceived, intentionally-developed, and powerfully-delivered campus rituals can have a tremendous impact on identity development, institutional loyalty, and above all, a shared sense of community.

Boyer's (1990) influential, research-based conceptualization of community is the foundational framework upon which many college's and universities have staged efforts to connect - or reconnect - students to one another and foster affiliation on campus. The very concepts of student involvement (Astin, 1993) and engagement (Kuh, 2001) are intertwined with notions of community; further, a sense of community and belonging among students is one of the most important factors in student success (Pascarella \& Terenzini, 2005). If campus rituals and 
ceremonies are indeed communal behaviors, we can intuit that participation in such celebrations and displays of campus culture is a powerful form of engagement that has the capacity to pay significant intellectual and emotional dividends.

The examples here are but a small sample of the many rituals and ceremonies that colleges and universities participate in annually across the country, their purpose to socialize and acclimatize entering students to the institutional milieu. Some of the traditions are deeply embedded in the institutional ethos, having been inaugurated sometime early in the institution's history and preserved through the years by generations of students. Other campus rituals and ceremonies have emerged, many unintentionally, out a particular historical moment in time; while many of these traditions have been inextricably linked to the prevailing societal norms and behaviors of the time, they have managed to survive and be meaningful and useful beyond their years.

A caveat is in order about ritualistic and ceremonial behaviors on the college campus. The fact remains that students will develop their own rituals to fill the void if none are available on campus. If colleges and universities are more proactive in creating a rich cultural environment, they will have the opportunity to put their imprint on the students and shape the entering student experience in a more constructive manner. For every ritual of orientation, there is a ritual of disorientation; for every ritual of integration, there is one of disintegration; and for every ritual of engagement, there is a ritual of disengagement and even rebellion or resistance. While institutions of higher education can not - and should not - seek to control all aspects of ritualistic and ceremonial behavior on campus, they do have an unprecedented opportunity to shape the discussion and move the cultural needle in more positive and educationally purposeful directions. The case to be made here is that institutions should more effectively use campus rituals and ceremonies to help students better understand themselves and their peer networks in relationship to the college or university they call home.

\section{References}

Astin, A.W. (1993). What matters in college? San Francisco: Jossey-Bass.

Boyer, E. (1990). Campus life: In search of community. San Francisco, CA: The

Carnegie Foundation for the Advancement of Teaching.

Geertz, C. (1973). The interpretation of cultures. New York: Basic Books.

Giovanelli, L. (2006, September 5). Instant Tradition: Orientations adding new rituals to instill school pride, suggest links with the past. Winston-Salem Journal Online. Retrieved August 10, 2007, http://www.journalnow.com/servlet /Satellite?pagename=WSJ/MGArticle/WSJ_BasicArticle\&path=!localnews!educa tion! \&cid=1149190419718\&c=MGArticle

Kenyon College. (2007). Kenyon traditions. Retrieved August 1, 2007, from http://www.kenyon.edu/x647.xml

Kroeber, A.L., \& Parsons, T. (1958). The concept of culture and of social system. American Sociological Review, 9, 582-583.

Kuh, G. D. (2001, May-June). Assessing what really matters to student learning: 
Inside the National Survey of Student Engagement. Change, 33(10), 10-17. Kuh, G. D., \& Whitt, E. J. (1988). The invisible tapestry: Culture in American colleges and universities (ASHE-ERIC Higher Education Report, No. 1). Washington, DC: Association for the Study of Higher Education.

Kuh, G. D., Siegel, M. J., \& Thomas, A. D. (2001). Higher education: Values and culture. In R. B. Winston, D. G. Creamer, and T. K. Miller and Associates (Eds.), The professional student affairs administrator: Educator, leader, and manager. New York: Brunner-Routledge.

Magolda, P. M. (2001). What our rituals tell us about community on campus: A look at the campus tour. About Campus, 5(6), 2-8.

Manning, K. (2000). Rituals, ceremonies, and cultural meaning in higher education. Westport, CT: Bergin \& Garvey.

Pascarella, E., \& Terenzini, P. (2005). How college affects students. San Francisco: Jossey Bass.

Salem College. (2002). About Salem: Traditions. Retrieved August 14, 2007, from http://www.salem.edu/old/about/traditions.php

Smith, B. (2005, September 1). Seeds of excellence sown under oaks. The Pendulum Online. Retrieved July 16, 2007, from http://www.elon.edu/e-web/pendulum/ Issues/2005/09_01/news/excellence.xhtml

Texas A \& M University. (2004). The fishcamp experience. Retrieved August 16, 2007, from http://fishcamp.tamu.edu/experience.html

Texas A \& M University. (2006). Fish camp - unique Aggie freshman experience. Retrieved August 16, 2007, from http://www.tamu.edu/home/spotlight/ archives/fishcamp.html

The College of William and Mary. (2005, December 20). 2005 Yule Log Ceremony mixes revelry and reflection. Retrieved July 30, 2007, from http://www.wm.edu/ news/?id $=5460$

Toma, J. D., Dubrow, G., \& Hartley, M. (2005). The uses of institutional culture: Strengthening identification and building brand equity in higher education (ASHE Higher Education Report, Vol. 31). San Francisco: Jossey-Bass.

Trice, H. M. (1984). Rites and ceremonials in organizational culture. In S. B. Bacharach \& S. M. Mitchell (Eds.), Perspectives on organizational sociology: Theory and research (Vol. 4). Greenwich, CT.: JAI Press.

Trice, H. M., \& Beyer, J. M. (1984). Studying organizational cultures through rites and ceremonials. The Academy of Management Review, 9(4), 653-669.

van Gennep, A. (1909). Les rites de passage. Paris: Nourry.

van Gennep, A. (1960). The rites of passage. (Translated by Monika B. Vizedom and Gabrielle L. Caffee). Chicago: University of Chicago Press.

Williams College. (2007). Williams traditions. Retrieved August 17, 2007, from http://www.williams.edu/admission/history_traditions.php

Yale Daily News. (2007). The insider's guide to the colleges. New York: St. Martin's Press.

Young, R. B. (1999, September-October). Reexamining our rituals. About Campus, 4(4), 10-16. 